\title{
Evaluation of hepatoprotective and antioxidant activity of Ichnocarpus frutescens (Linn.) R.Br. on paracetamol-induced hepatotoxicity in rats
}

\author{
Deepak K. Dash ${ }^{1,2}$, Veerendra C. Yeligar ${ }^{2}$, Siva S. Nayak ${ }^{2}$, \\ Tirtha Ghosh ${ }^{3}$, D. Rajalingam ${ }^{2}$, Pinaki Sengupta ${ }^{2}$, Bhim C. \\ Maiti $^{2}$, Tapan K. Maity ${ }^{2 *}$. \\ ${ }^{1}$ College of Pharmaceutical Sciences, Mohuda, Berhampur, Orissa, India. \\ ${ }^{2}$ Division of Pharmaceutical Chemistry, Department of Pharmaceutical Technology, Jadavpur University, Kolkata- \\ 700032, India. ${ }^{3}$ Institute of Pharmacy and Technology, Salipur, Orissa-754202, India
}

\begin{abstract}
Purpose: The entire plant including the flowers, of Ichnocarpus frutescens R.Br. (Apocynaceae) has been used for the treatment of cancer, skin infections, diabetes and liver disorder. The present study is aimed at evaluating the hepatoprotective effect of chloroform and methanol extract (CEIF and MEIF) of whole plant of I. frutescens (Linn.) by paracetamol-induced liver damage in rats.

Methods: The chloroform and methanolic extracts of I. frutescens (CEIF and MEIF) were studied for their hepatoprotective and antioxidant effects on paracetamol $(750 \mathrm{mg} / \mathrm{kg})$ induced acute liver damage on Wistar albino rats. The degree of protection was measured by using biochemical parameters such as serum glutamate oxalate transaminase (SGOT) and serum glutamate pyruvate transaminase (SGPT), alkaline phosphatase (ALP), bilirubin and total protein. Further, the effects of both extracts on lipid peroxidation (LPO), glutathione (GSH), superoxide dismutase (SOD) and catalase (CAT) were estimated.

Results: CEIF and MEIF at a dose level of $250 \mathrm{mg} / \mathrm{kg}$ and $500 \mathrm{mg} / \mathrm{kg}$ produce significant $(P<0.05)$ hepatoprotection by decreasing the activity of serum enzymes, bilirubin, and lipid peroxidation, while they significantly increased the levels of Glutathione (GSH), superoxide dismutase (SOD) and catalase $(C A T)$ in a dose dependent manner. The effects of CEIF and MEIF were comparable to that of standard drug, Silymarin.

Conclusion: From this study, it can be concluded that the chloroform and methanol extract of I. frutescens is not only an effective hepatoprotective agent, but also possesses significant $(p<0.05)$ antioxidant activity.
\end{abstract}

Keywords: Ichnocarpus frutescens, Hepatoprotective effect, Antioxidant role, Paracetamol.

${ }^{*}$ Corresponding Author: Tel: +913324146074 E-mail: jutkmaity@yahoo.com 


\section{INTRODUCTION}

Aerobic organs such as the liver generate reactive oxygen species that induce oxidative tissue damage. These radicals, which react with cell membranes and thus induce lipid peroxidation or cause inflammation, have been implicated as important pathological mediators in many clinical disorders such as heart disease, diabetes, gout and cancer ${ }^{1-3}$. A major defence mechanism is the antioxidant enzymes, which convert active oxygen molecules into non-toxic compounds ${ }^{4,5}$.

Liver diseases remain as one of the serious health problems. However we do not have satisfactory liver protective drugs in allopathic medical practice for serious liver disorders. Herbal drugs play a role in the management of various liver disorders most of which speed up the natural healing processes of the liver. Numerous medicinal plants and their formulations are used for liver disorders in ethnomedical practice as well as traditional system of medicine in India. More than fifteen of these plants are evaluated for their hepatoprotective action in light of modern medicine ${ }^{6}$.

The plant Ichnocarpus frutesecens (linn). R.Br. (Family: Apocynaceae) is a large much branched twining shrub; young branches finely fulvous-tomentose. Leaves $4.5-7.5$ by $2-3.8 \mathrm{~cm}$, elliptic-oblong, acute or acuminate, glabrous above, glabrous or slightly pubescent and pale beneath, base usually rounded, occasionally found in village surroundings and hedges throughout India ${ }^{7}$. It is locally called Botilai and the plant is used by the local peoples of Mohuda, Berhampur, Orissa, India for simple fevers and to treat liver disorder. The whole plant is used as a tribal medicine in atrophy, bleeding gums, cough and dysentery ${ }^{8}$. Stalk and leaves in decoction is used in the treatment of skin eruptions. A decoction of the roots of Colocynth, Anantamul, Sariva (Sanskrit) and Hedyotis biflora prepared in the usual way is administered with the addition of powdered long pepper and bdellium in chronic skin diseases, syphilis, loss of sensation and hemiplegia ${ }^{9}$.

Silymarin is a flavonolignan that has been introduced fairly recently as a hepatoprotective agent. Silymarin is extracted from the seeds and fruits of Silybum marianum and in reality is a mixture of three structural components: Silibinin, Silydianine and Silychristine.

Clinical trials have shown that Silymarin exerts hepatoprotective effects in acute viral hepatitis, poisoning by Amanita phalloides, ethanol, paracetamol, and carbon tetrachloride. Many studies have demonstrated the beneficial hepatoprotective effects when treatment with Silymarin ${ }^{10}$.

However, no work has been reported on the hepatoprotective properties of this plant. Keeping this in view, the present study has been undertaken to investigate hepatoprotective activity and antioxidant role of the chloroform and methanol extract (CEIF \& MEIF) of Ichnocarpus frutescens (Linn) on paracetamol induced liver damage in rats.

\section{MATERIALS AND METHODS Plant Materials}

The plant Ichnocarpus frutescens (Family: Apocynaceae) was collected from Mohuda forest area, Ganjam district, Berhampur, Orissa, India in the month of September. The plant material was taxonomically identified by the taxonomists of Botanical Survey of India, Kolkata. A voucher specimen (NO.CNH/l-I (98)/2005/Tech.II/1448) has been preserved in our laboratory for future reference.

\section{Extraction}

The whole plant was dried under shade and then powered with a mechanical grinder to obtain a coarse powder, which was then subjected to successive extraction in a Soxhlet apparatus using petroleum ether $\left(60-80{ }^{\circ} \mathrm{C}\right)$, chloroform and methanol. Solvent elimination under reduced pressure afforded the chloroform extract (2\% w/w yield) and methanol extract $(17 \% \mathrm{w} / \mathrm{w}$ yield) respectively. The resulting chloroform and 
methanol extracts were then used for hepatoprotective and in vivo antioxidant studies.

\section{Experimental Animals}

Studies were carried out using male Wistar albino rats $(150-200 \mathrm{~g})$. They were obtained from the animal house, Indian Institute of Chemical Biology (IICB), Kolkata, India. The animals were grouped and housed in polyacrylic cages (38 x $23 \times 10 \mathrm{~cm}$ ) with not more than six animals per cage and maintained under standard laboratory conditions (temperature $25 \pm 2^{\circ} \mathrm{C}$ ) with dark and light cycle $(12 / 12 \mathrm{~h})$. The animals were fed with standard pellet diet supplied by Hindustan Lever Ltd., Kolkata, India and fresh water ad libitum. All the animals were acclimatized to laboratory condition for a week before commencement of experiment. All procedures described were reviewed and approved by the University Animals Ethical Committee.

\section{Drugs and Chemicals}

Silymarin was purchased from Micro labs, Tamilnadu. India SGOT, SGPT, ALP, Bilirubin and Total Protein kits were procured from Span Diagnostics, Surat, India. Thiobarbituric acid (TBA), Nitro blue tetrazolium chloride (NBT), Phenazine methosulphate were purchased from Central Drug House, New Delhi, India and 5,5'dithiobis-2-nitrobenzoic acid (DTNB), Reduced Glutathione (GSH) and the rest of the chemicals utilized were of analytical grade and were obtained from Sisco research laboratories, Mumbai, India.

\section{Paracetamol-induced hepatotoxicity in rats (Acute model)}

Animals were randomized and divided into seven groups (I-VII) of six animals in each group. Group I served as untreated control and fed orally with normal saline $5 \mathrm{ml} / \mathrm{kg}$ body weight daily for seven days. Group II rats were similarly treated as group I. Group III and IV were treated with $250 \mathrm{mg}$ and $500 \mathrm{mg} / \mathrm{kg}$ body weight of the chloroform extract and Group V and VI were treated with the methanolic extract orally daily for seven days respectively ${ }^{11}$. Animals of Group VII were fed with standard drug Silymarin $25 \mathrm{mg} / \mathrm{kg}^{12} ;$ p.o daily for seven days.
On the seventh day, paracetamol suspension was given by oral route, in a dose of $750 \mathrm{mg} / \mathrm{kg}$ body weight to all rats except the rats in group I .The biochemical parameters were estimated after an $18 \mathrm{~h}$ fast following the last dose.

\section{Biochemical studies}

The blood was obtained from all animals by puncturing retro-orbital plexus. The blood samples were allowed to clot for $45 \mathrm{~min}$ at room temperature. Serum was separated by centrifugation at $2500 \mathrm{rpm}$ at $30^{\circ} \mathrm{C}$ for $15 \mathrm{~min}$ and utilized for the estimation of various biochemical parameters namely SGOT, SGPT ${ }^{13}$, SALP $^{14}$, serum bilirubin ${ }^{15}$ and total protein ${ }^{16}$.

After collection of blood samples the rats in different groups were sacrificed and their livers were excised immediately and washed in ice cold normal saline, followed by $0.15 \mathrm{M}$ Tris- $\mathrm{Hcl}$ (pH 7.4) blotted dry and weighed. A $10 \% \mathrm{w} / \mathrm{v}$ of homogenate was prepared in $0.15 \mathrm{M}$ Tris- $\mathrm{Hcl}$ buffer and processed for the estimation of lipid peroxidation $^{17}$. A part of homogenate after precipitating proteins with Trichloroacetic acid (TCA) was used for estimation of glutathione ${ }^{18}$. The rest of the homogenate was centrifuged at $1500 \mathrm{rpm}$ for $15 \mathrm{~min}$ at $4^{0} \mathrm{C}$. The supernatant thus obtained was used for estimation of SOD and CAT activities ${ }^{19,20}$.

\section{Serum hepatospecific markers}

Activities of serum glutamate oxaloacetate transaminase (SGOT) and serum glutamate pyruvate transaminase (SGPT) were estimated by the method of Reitman and Frankel ${ }^{13} .0 .05 \mathrm{ml}$ of serum with $0.25 \mathrm{ml}$ of substrate (aspartate and $\alpha$-ketoglutarate for SGOT; alanine and $\alpha$ keto glutarate for SGPT, in phosphate buffer $\mathrm{pH}$ 7.4) was incubated for an hour in case of SGOT and $30 \mathrm{~min}$. for SGPT. $0.25 \mathrm{ml}$ of DNPH solution was added to arrest the reaction and kept for 20 $\mathrm{min}$ in room temperature. After incubation $1 \mathrm{ml}$ of $0.4 \mathrm{~N} \mathrm{NaOH}$ was added and absorbance was read at $505 \mathrm{~nm}$ in $u v$-vis spectrophotometer. Activities were expressed as IU/L.

Based on the method of King and Armstrong ${ }^{14}$ alkaline phosphatase activity was assayed using 
disodium phenyl phosphate as substrate. The colour developed was read at $510 \mathrm{~nm}$ in $u v$-vis spectrophotometer after 10 min. Activities of ALP was expressed as IU/L. Serum total bilirubin level was estimated based on the method of made up to $4 \mathrm{ml}$ with distilled water and then heated at $95^{\circ} \mathrm{C}$ in a water bath for $60 \mathrm{~min}$. After incubation the tubes were cooled to room temperature and the final volume was made upto $5 \mathrm{ml}$ in each tube. Then $5 \mathrm{ml}$ of $\mathrm{n}$-butanol:

Table 1: Effect of CEIF, MEIF and Silymarin on serum enzymes (SGPT, SGOT and ALP), Total bilirubin and total protein on paracetamol induced liver damage in rats.

\begin{tabular}{|c|c|c|c|c|c|c|}
\hline Groups and treatment & $\begin{array}{c}\text { Dose } \\
(\mathrm{mg} / \mathrm{kg})\end{array}$ & $\begin{array}{l}\text { SGOT } \\
(\text { IU/L) }\end{array}$ & $\begin{array}{l}\text { SGPT } \\
\text { (IU/L) }\end{array}$ & $\begin{array}{l}\text { SALP } \\
(I U / L)\end{array}$ & $\begin{array}{c}\text { Total } \\
\text { Bilirubin } \\
\text { (mg/dl) }\end{array}$ & $\begin{array}{l}\text { Total } \\
\text { Protein } \\
\text { (mg/dl) }\end{array}$ \\
\hline $\begin{array}{l}\text { Group I- Normal } \\
(\mathrm{NaCl} 0.9 \% \mathrm{w} / \mathrm{v})\end{array}$ & $5 \mathrm{ml} / \mathrm{kg}$ & $45.17 \pm 2.40$ & $57.33 \pm 2.33$ & $16.13 \pm 1.36$ & $1.60 \pm 0.14$ & $7.91 \pm 0.49$ \\
\hline $\begin{array}{l}\text { Group II- Paracetamol } \\
\text { control }\end{array}$ & $750 \mathrm{mg} / \mathrm{kg}$ & $118.50 \pm 1.72^{*}$ & $\begin{array}{l}114.00 \pm \\
2.67^{*}\end{array}$ & $32.24 \pm 1.96^{*}$ & $6.20 \pm 0.63^{*}$ & $\begin{array}{l}5.06 \pm \\
0.20^{*}\end{array}$ \\
\hline $\begin{array}{l}\text { Group III- CEIF + } \\
\text { Paracetamol }\end{array}$ & $\begin{array}{l}250 \mathrm{mg} / \mathrm{kg}+ \\
750 \mathrm{mg} / \mathrm{kg}\end{array}$ & $83.67 \pm 3.16^{* *}$ & $\begin{array}{l}77.50 \pm \\
1.87^{\star *}\end{array}$ & $\begin{array}{l}22.92 \pm \\
1.11^{* *}\end{array}$ & $3.36 \pm 0.16$ & $\begin{array}{l}6.06 \pm \\
0.10^{* \star}\end{array}$ \\
\hline $\begin{array}{l}\text { Group IV- CEIF + } \\
\text { Paracetamol }\end{array}$ & $\begin{array}{l}500 \mathrm{mg} / \mathrm{kg} \\
+750 \mathrm{mg} / \mathrm{kg}\end{array}$ & $68.17 \pm 1.74^{* *}$ & $\begin{array}{l}67.50 \pm \\
1.48^{* *}\end{array}$ & $\begin{array}{l}19.71 \pm \\
1.27^{\star \star}\end{array}$ & $2.95 \pm 0.35^{\star \star}$ & $\begin{array}{l}6.90 \pm \\
0.19^{* *}\end{array}$ \\
\hline $\begin{array}{l}\text { Group V- MEIF + } \\
\text { Paracetamol }\end{array}$ & $\begin{array}{l}250 \mathrm{mg} / \mathrm{kg}+ \\
750 \mathrm{mg} / \mathrm{kg}\end{array}$ & $80.67 \pm 2.25^{\star *}$ & $\begin{array}{l}68.33 \pm \\
2.06^{* *}\end{array}$ & $\begin{array}{l}20.39 \pm \\
1.99^{\star *}\end{array}$ & $2.68 \pm 0.35^{\star \star}$ & $\begin{array}{l}6.85 \pm \\
0.23^{\star *}\end{array}$ \\
\hline $\begin{array}{l}\text { Group VI- MEIF + } \\
\text { Paracetamol }\end{array}$ & $\begin{array}{l}500 \mathrm{mg} / \mathrm{kg} \\
+750 \mathrm{mg} / \mathrm{kg}\end{array}$ & $58.33 \pm 2.00^{* *}$ & $\begin{array}{l}59.50 \pm \\
1.99^{\star *}\end{array}$ & $\begin{array}{l}17.11 \pm \\
1.34^{\star \star}\end{array}$ & $2.18 \pm 0.15^{\star *}$ & $\begin{array}{l}7.41 \pm \\
0.35^{\star \star}\end{array}$ \\
\hline $\begin{array}{l}\text { Group VII- Silymarin + } \\
\text { Paracetamol }\end{array}$ & $\begin{array}{l}25 \mathrm{mg} / \mathrm{kg} \\
+750 \mathrm{mg} / \mathrm{kg}\end{array}$ & $55.50 \pm 1.61^{* *}$ & $\begin{array}{l}58.67 \pm \\
2.29^{\star *}\end{array}$ & $\begin{array}{l}17.43 \pm \\
1.63^{* *}\end{array}$ & $1.97 \pm 0.22^{\star \star}$ & $\begin{array}{l}7.99 \pm \\
0.41^{\star \star}\end{array}$ \\
\hline
\end{tabular}

Values are Mean \pm SEM; $n=6$ animals in each group; ${ }^{*} P<0.05$ is considered significant when compared with group I; ${ }^{* *} \mathrm{P}<0.05$ is considered significant when compared with group II by Dunnett's multiple comparison test.

Malloy and Evelyn ${ }^{15}$. Diazotised sulphonilic acid $(0.25 \mathrm{ml})$ reacts with bilirubin in diluted serum $(0.1 \mathrm{ml}$ serum $+0.9 \mathrm{ml}$ distilled water) and forms purple colored azobilirubin, which was measured at $540 \mathrm{~nm}$ in $u v$-vis spectrophotometer. Activities of total bilirubin were expressed as $\mathrm{mg} / \mathrm{dl}$. Serum total protein level was estimated based on the method of Gornall et $a l^{16}$. Biuret reagent $(1.0 \mathrm{ml})$ reacts with serum $(10 \mu \mathrm{L})$ and the colour developed was read at $578 \mathrm{~nm}$ in $u v$-vis spectrophotometer. Activities of total protein was expressed as $\mathrm{mg} / \mathrm{dl}$.

\section{Determination of Thiobarbituric Acid Reactive Substances (TBARS)}

Lipid peroxidations in liver tissues were estimated colorimetrically by measuring thiobarbituric acid reactive substances (TBARS) by the method of Ohkawa et al $1^{17}$. To $0.2 \mathrm{ml}$ of sample, $0.2 \mathrm{ml}$ of $8.1 \%$ Sodium dodecyl sulfate, $1.5 \mathrm{ml}$ of $20 \%$ acetic acid and $1.5 \mathrm{ml}$ of $0.8 \%$ TBA were added. The volume of the mixture was
Pyridine mixture was added and the contents were vortexed thoroughly for $2 \mathrm{~min}$. After centrifugation at $3000 \mathrm{rpm}$ for $10 \mathrm{~min}$ the upper organic layer was taken and its OD was read at $532 \mathrm{~nm}$ against an appropriate blank without the sample. The levels of lipid peroxides were expressed as milimoles of thiobarbituric acid reactive substances (TBARS)/100gram of liver tissue using an extinction co-efficient of $1.56 \times 10$ ${ }^{5} \mathrm{M}^{-1} \mathrm{~cm}^{-1}$.

\section{Determination of reduced glutathione (GSH)}

Reduced glutathione (GSH) was determined by the method of Ellman ${ }^{18}$. To $0.1 \mathrm{ml}$ of different tissue homogenate $2.4 \mathrm{ml}$ of $0.02 \mathrm{M}$ EDTA solution was added and kept on ice bath for 10 $\mathrm{min}$. Then $2 \mathrm{ml}$ of distilled water and $0.5 \mathrm{ml}$ of 50 $\%$ TCA were added. This mixture was kept on ice for $10-15 \mathrm{~min}$ and then centrifuged at 3000 rpm for $15 \mathrm{~min} .1 \mathrm{ml}$ of supernatant was taken and $2 \mathrm{ml}$ of Tris-Hcl buffer was added. Then 0.05 
$\mathrm{ml}$ of DTNB solution (Ellman's reagent) was added and vortexed thoroughly. OD was read (within 2-3min after the addition of DTNB) at 412 $\mathrm{nm}$ against a reagent blank. Absorbance values were compared with a standard curve generated from known GSH.

\section{Assay of super oxide dismutase (SOD)}

Superoxide dismutase (SOD) activity was determined by the method of Kakkar et $\mathrm{al}^{19}$. The assay mixture contained $0.1 \mathrm{ml}$ of sample, $1.2 \mathrm{ml}$ of sodium pyrophosphate buffer $(\mathrm{pH} 8.3,0.052$ $\mathrm{M}), 0.1 \mathrm{ml}$ of phenazine methosulphate $(186 \mu \mathrm{m})$, $0.3 \mathrm{ml}$ of nitro blue tetrazolium $(300 \mu \mathrm{m}), 0.2 \mathrm{ml}$ of NADH $(750 \mu \mathrm{m})$. Reaction was started by addition of NADH. After incubation at $30^{\circ} \mathrm{C}$ for $90 \mathrm{sec}$, the reaction was stopped by the addition of $0.1 \mathrm{ml}$ of glacial acetic acid. The reaction mixture was stirred vigorously with $4.0 \mathrm{ml}$ of $\mathrm{n}$ butanol. The mixture was allowed to stand for 10 min, centrifuged and butanol layer was separated. The colour intensity of the chromogen in butanol layer was measured at $560 \mathrm{~nm}$ against $\mathrm{n}$-butanol and concentration of SOD was expressed as units/g of liver tissue. Absorbance values were compared with a standard curve generated from known SOD.

\section{Assay of Catalase (CAT)}

Catalase was assayed according to the method of $\mathrm{Aebi}^{20}$. The estimation was done spectrophotometrically following the decrease in absorbance at $230 \mathrm{~nm}$. The liver tissue was homogenized in $\mathrm{M} / 150$ phosphate buffer $(\mathrm{pH}$ 7.0) at $1-4^{0} \mathrm{C}$ and centrifuged at $5000 \mathrm{rpm}$. The reaction mixture contained $0.01 \mathrm{M}$ phosphate buffer ( $\mathrm{pH}$ 7.0), $2 \mathrm{mM} \mathrm{H}_{2} \mathrm{O}_{2}$ and the enzyme extract. The specific activity of catalase was expressed in terms of units/gram of liver tissue. Absorbance values were compared with a standard curve generated from known CAT.

\section{Histopathological study}

Small pieces of liver tissues in each group were collected in $10 \%$ neutral buffered formalin for proper fixation. These tissues were processed and embedded in paraffin wax. Sections of 5$6 \mu \mathrm{m}$ in thickness were cut and stained with hematoxylin and eosin (H\&E). These sections were examined photo microscopically for necrosis, steatosis and fatty changes of hepatic cells.

\section{Statistical analysis}

The experimental results were expressed as the Mean \pm SEM for six animals in each group. The biochemical parameters were analysed statistically using one-way analysis of variance ANOVA, followed by Dunnett's mutiple comparison test (DMCT). $P$ value of $<0.05$ was considered as statistically significant.

\section{RESULTS}

The effects of CEIF and MEIF on serum transaminase, alkaline phosphatase, bilirubin and total protein levels in paracetamol-induced liver damage in rats are summarized in Table-1. Administration of paracetamol $(750 \mathrm{mg} / \mathrm{kg}$; body weight), after 18 hours of intoxication resulted a significant $(P<0.05)$ elevation of hepatospecific serum markers SGOT, SGPT, SALP, bilirubin and total protein in paracetamol-treated group, in comparison with the normal control group. On administration of CEIF and MEIF (Group III to VI, Table-1) and Silymarin at the dose of $25 \mathrm{mg} / \mathrm{kg}$ (Group VII, Table-1) the level of these enzymes were found retrieving towards normalcy.

The effects of CEIF and MEIF on rat liver lipid peroxidation, glutathione and enzymic antioxidants namely SOD and CAT levels are shown in Fig. 1 to 4 . The levels of TBARS were considerably increased in rats treated with paracetamol as compared to the normal rats. Treatment with CEIF and MEIF (250 mg and 500 $\mathrm{mg} / \mathrm{kg} /$ day) resulted in a significant decrease $(P<0.05)$ in levels of TBARS and brought them near to normal level (Fig. 1). A significant decrease in the activities of glutathione and enzymic antioxidants (SOD and CAT) were noted after single administration of paracetamol. Upon administration of CEIF and MEIF, the activities of glutathione and enzymic antioxidants were significantly $(P<0.05)$ reversed to near normal (Fig.2 to 4). The effects of CEIF and MEIF were comparable with that of standard reference drug Silymarin.

Histopathological studies of rat liver tissue from Group I animals show normal hepatic cells with 


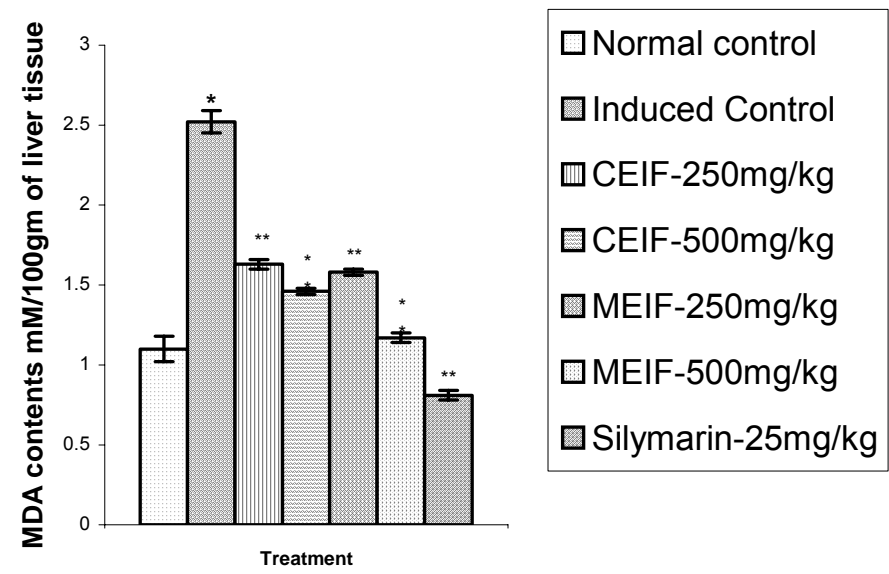

Values are mean \pm SEM, $(n=6)$; * $P<0.05$ (Statistically significant compared with normal control); ${ }^{\star \star} P<0.05$ (Statistically significant compared with induced control).

Fig.1 Effect of CEIF and MEIF on TBARS Level in liver tissues

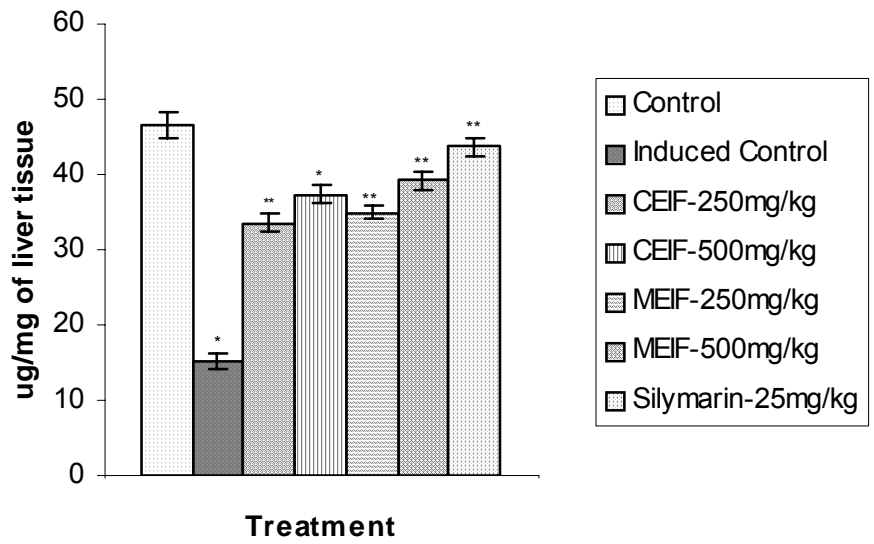

Values are mean \pm SEM, $(n=6) ; * P<0.05$ (Statistically significant compared with normal control) $; * * P<0.05$ (Statistically significant compared with induced control).

Fig. 2 Effect of CEIF and MEIF on GSH Level 


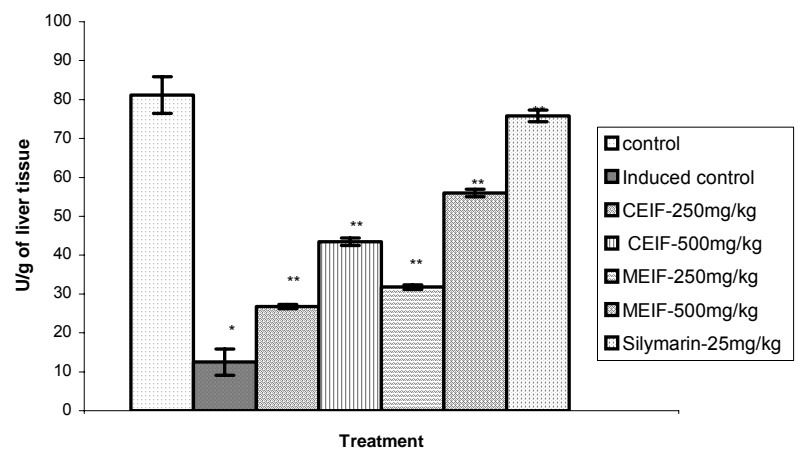

Values are mean \pm SEM, $(n=6) ;{ }^{*} P<0.05$ (Statistically significant compared with normal control); ${ }^{*} P<0.05$ (Statistically significant compared with induced control).

Fig. 3 Effect of CEIF and MEIF on SOD level

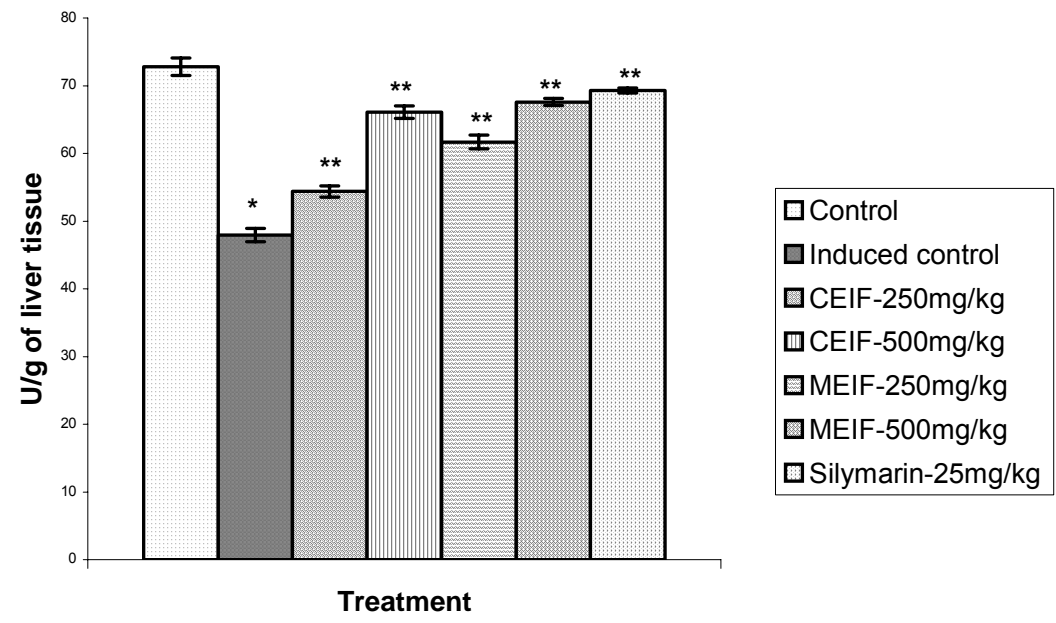

Values are mean \pm SEM, $(n=6)$; ${ }^{*} P<0.05$ (Statistically significant compared with normal control); ${ }^{\star} P<0.05$ (Statistically significant compared with induced control).

Fig. 4 Effect of CEIF and MEIF on CAT level 
Maity et al

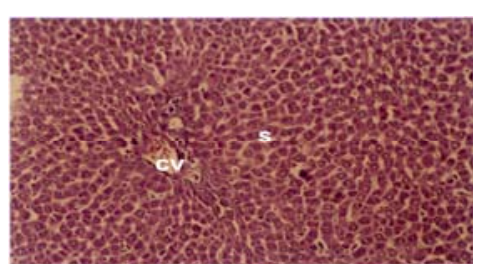

Fig.5: Photomicrograph of liver tissue of control rats showing normal hepatic cells with central vein (CV) and sinusoidal dilation (S) ( $H \& E, 100 x)$

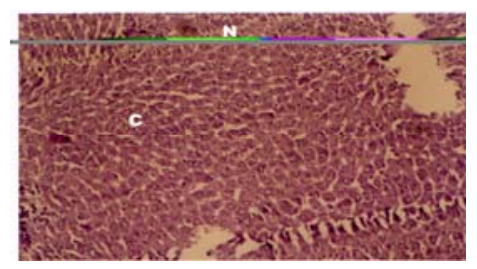

Fig.7: Photomicrograph of liver tissue of rats treated with CEIF at 250mg/kg (Gr III) showing mild degree of necrosis $(N)$ with normal cells $(C)(H \& E, 100 x)$

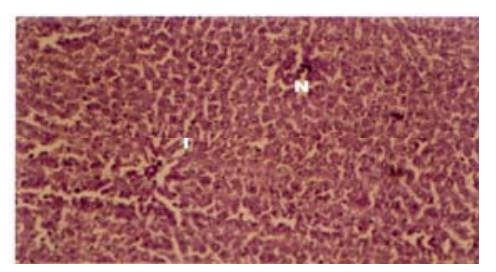

Fig. 9: Photomicrograph of liver tissue of rats treated with MEIF at $250 \mathrm{mg} / \mathrm{kg}$ (Gr V) showing mild degree of necrosis $(N)$ with areas of inflammation (1) adjucent to necrosied area (H\& E, 100x)

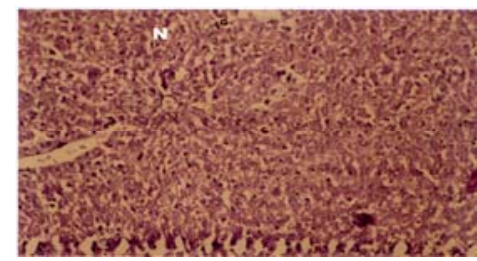

Fig.6: Photomicrograph of liver tissue of rats treated with paracetamol showing severe necrosis $(N)$ with disappearance of nuclei $(H \&$ E, 100x)

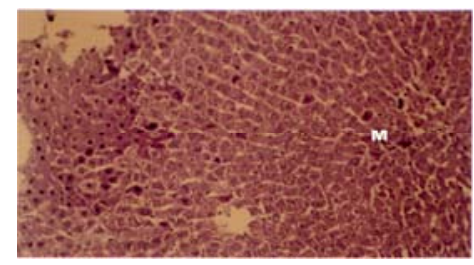

Fig. 8: Photomicrograph of liver tissue of rats treated with CEIF at $500 \mathrm{mg} / \mathrm{kg}$ (Gr IV) showing normal hepatocytes with regenerating hepatocytes and mild inflammation in the portal area $(M)(H \&$ E, 100x)

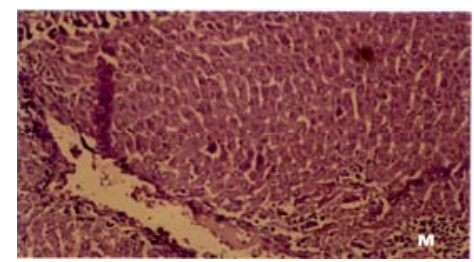

Fig.10: Photomicrograph of liver tissue of rats treated with MEIF at $500 \mathrm{mg} / \mathrm{kg}$ (Gr VI) showing normal hepatocytes with mild inflammation of portal triad $(M)(H \& E, 100 x)$

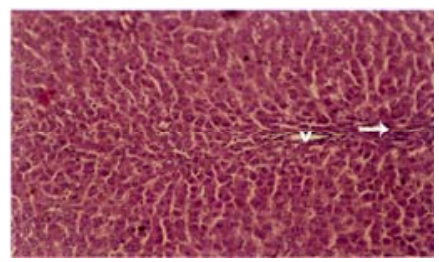

Fig.11 Photomicrograph of liver tissue treated with Silymarin at $25 \mathrm{mg} / \mathrm{kg}$ showing normal hepatocytes, portal vein $(V)$ and portal artery (Arrow) (H\& E, 100x) 
central vein (V) and sinusoidal dilation (Fig. 5). In paracetamol treated group (Group II), severe hepatotoxicity was observed by severe necrosis (N) with disappearance of nuclei (Fig. 6). Mild degree of necorsis $(\mathrm{N})$ with normal cells $(\mathrm{C})$ was observed in Group III and mild degree of necrosis $(\mathrm{N})$ with areas of inflammation adjacent to necrosised area was observed in Group V animals, treated with CEIF and MEIF $(250 \mathrm{mg} / \mathrm{kg} /$ day) respectively (Fig. 7 and 9$)$ while normal hepatocytes with regenerating hepatocytes and mild inflammation in the portal area (M) was observed with Group IV and normal hepatocytes with mild inflammation of portal tried (M) was observed with group $\mathrm{VI}$ animals at the dose of $500 \mathrm{mg} / \mathrm{kg} /$ day of CEIF and MEIF respectively (Fig.8 and 10). The liver taken from Group VII animals treated with standard drug Silymarin showed the normal hepatic cells with portal vein (V) and portal artery (Fig. 11).

\section{DISCUSSION}

Paracetamol (acetaminophen) is a commonly and widely used analgesic and antipyretic agent. Hepatotoxic doses of acetaminophen deplete the normal levels of hepatic glutathione, when NAPQI covalently binds to cysteine groups on proteins to form 3-(cystein-S-yl) acetaminophen adducts $^{21}$. The glutathione protects hepatocytes by combining with the reactive metabolite of paracetamol thus preventing their covalent binding to liver proteins ${ }^{22}$.

In living systems, liver is considered to be highly sensitive to toxic agents. The study of different enzyme activities such as SGOT, SGPT, SALP, total bilirubin and total protein have been found to be of great value in the assessment of clinical and experimental liver damage ${ }^{23}$. In the present investigation it was observed that the animals treated with acetaminophen resulted in significant hepatic damage as shown by the elevated levels of serum markers. These changes in the marker levels will reflect in hepatic structural integrity. The rise in the SGOT is usually accompanied by an elevation in the levels of SGPT, which play a vital role in the conversion of amino acids to keto acids ${ }^{24}$. The pretreatment with CEIF and MEIF, both at the dose of $250 \mathrm{mg} / \mathrm{kg}$ and $500 \mathrm{mg} / \mathrm{kg}$, significantly attenuated the elevated levels of the serum markers. The normalization of serum markers by CEIF and MEIF suggests that they are able to condition the hepatocytes so as to protect the membrane integrity against acetaminopheninduced leakage of marker enzymes into the circulation. The above changes can be considered as an expression of the functional improvement of hepatocytes, which may be caused by an accelerated regeneration of parenchyma cells. Serum ALP and bilirubin levels, on the other hand are related to hepatic cell damage. Increase in serum level of ALP is due to increased synthesis in presence of increasing billiary pressure ${ }^{25}$. Effective control of bilirubin level and alkaline phosphatase activity points towards an early improvement in the secretory mechanism of the hepatic cell.

Lipid peroxidation has been postulated to the destructive process of liver injury due to acetaminophen administration. In the present study the elevations in the levels of end products of lipid peroxidation in the liver of rat treated with paracetamol were observed. The increase in malondialdehyde (MDA) levels in liver suggests enhanced lipid peroxidation leading to tissue damage and failure of antioxidant defense mechanisms to prevent formation of excessive free radicals. Treatment with CEIF and MEIF significantly reversed these changes. Hence it may be possible that the mechanism of hepatoprotection by CEIF and MEIF is due to its antioxidant effect.

The non-enzymic antioxidant, glutathione is one of the most abundant tripeptides present in the liver. Its functions are mainly concerned with the removal of free radical species such as hydrogen peroxide, superoxide radicals, alkoxy radicals, and maintenance of membrane protein thiols and as a substrate for glutathione peroxidase and GST ${ }^{26}$. In our present study the decreased level of GSH has been associated with an enhanced lipid peroxidation in paracetamol-treated rats. Administration of CEIF and MEIF significantly increased the level of glutathione in a dose-dependent manner. 
The enzymic antioxidant defense system is the nature protector against lipid peroxidation. SOD, CAT and GPx enzymes are important scavengers of superoxide ion and hydrogen peroxide. These enzymes prevent generation of hydroxyl radical and protect the cellular constituents from oxidative damage ${ }^{27}$. In the present study, it was observed that the CEIF and MEIF significantly increased the hepatic SOD activity in paracetamol induced liver damage in rats. This show CEIF and MEIF can reduce reactive free radicals that might lessen oxidative damage to the tissues and improve the activities of the hepatic antioxidant enzyme.

Catalase (CAT) is an enzymatic antioxidant widely distributed in all animal tissues and the highest activity is found in the red cells and in the liver. CAT decomposes hydrogen peroxide and protects the tissue from highly reactive hydroxyl radicals ${ }^{28}$. Therefore the reduction in the activity of these enzymes may result in a number of deleterious effects due to the accumulation of superoxide radicals and hydrogen peroxide. Administration of CEIF and MEIF increased the activities of CAT in paracetamol-induced liver damage in rats to prevent the accumulation of excessive free radicals and protected the liver from paracetamol intoxication.

The histopathological observations in paracetamol-treated rats showed severe necrosis, with disappearnce of nuclei. This could be due to the formation of highly reactive radicals because of oxidative threat caused by paracetamol. All these changes were very much reduced histopathologically in rats treated with CEIF and MEIF. Based on the above results, it could be concluded that CEIF and MEIF exerts significant hepatoprotection against paracetamol-induced toxicity.

\section{CONCLUSION}

The present investigation indicates that CEIF and MEIF exert significant protection against paracetamol-induced toxicity by its ability to ameliorate the lipid peroxidation through the free radicals scavenging activity, which enhanced the levels of antioxidant defense system. Our study also showed that MEIF in the dose of $250 \mathrm{mg} / \mathrm{kg}$ and $500 \mathrm{mg} / \mathrm{kg}$ has greater effect than CEIF at the same dose level. Therefore MEIF appears to be useful in the attenuation of paracetamolinduced lipid peroxidation and showed more prominent effect than CEIF. Both the extract showed significant activity against paracetamol induced liver damage in rats when compared with that of standard drug silymarin. Further investigation is underway to determine the exact phytoconstituents in the extracts that are responsible for its hepatoprotective effect.

\section{Acknowledgement}

One of the authors Deepak Kumar Dash, Senior Research Fellow is grateful to the authority of College of Pharmaceutical Sciences, Mohuda, Berhampur, Orissa for sanctioning study leave and the authority of Jadavpur University for providing all facilities.

\section{REFERENCES}

1. Slater TF. Free-radical mechanism in tissue injury. Biochem J 1984; 222: 1-15.

2. Vuillaume $M$. Reduced oxygen species, mutation, induction and cancer initiation. Mutat Res 1987; 186: 43-72.

3. Meneghini R. Genotoxicity of active oxygen species in mammalian cells. Mutat Res 1988; 195: 215-230.

4. Halliwell B, Gutteridge JMC. Lipid peroxidation, oxygen radicals, cell damage and antioxidant therapy. Lancet 1984; 23: 1396-1397.

5. Hochstein $P$, Atallah AS. The nature of oxidants and antioxidant systems in the inhibition of mutation and cancer. Mutat Res 1988; 202: 363-375.

6. Subramoniam A, Evans DA, Rajasakhran SP Hepatoprotective activity of Trichopus zeylanicus extracts against paracetamol induced damage in rats. Ind J Expt Biol 1998; 36: 385-389.

7. Kirtikar KR, Basu BD. Indian Medicinal Plants, Allahabad, Lalit Mohan Basu Publications, 1998, pp 1590-1592.

8. Chatterjee A, Pakrashi SC. The Treatise on Indian Medicinal Plants, New Delhi, Publications and information Directorate, 1995, pp 110-112.

9. Nadkarni KM. The Indian Materia Medica, Bombay, Bombay Popular Prakashan, 1982, p 674.

10. Fraschini F, Demartini G, Esposti D. Pharmacology of Silymarin. Clin Drug Inv 2002; 22: 51-65.

11. Hiroshini $A$, Toshiharu $H$, Masahiro $H$, Sholi. An alteration in liver microsomal membrane of the rat following paracetamol overdose. $\mathrm{J}$ Pharm Pharmacol 1987; 39: 1047-1049.

12. VeereshwarayyaV, Thiruvengadam D. Hepatoprotective effect of allicin on tissue defense system in galactosamine/endotoxin challenged rats. J Ethno Pharmacol 2004; 90: 151-154. 


\section{Maity et al}

13. Retimen S, Frankel SA. Colorimetric method for determination of serum glutamic oxaloacetic and glutamic pyruvate transaminases. Am J Clin Pathol 1957; 28: 56-63.

14. King EJ, Armstrong AR. A convenient method for determining of Serum and bile phosphatase activity. J Canad. Med. Assoc 1934; 31: 376-381.

15. Malloy HT, Evelyn KA. The determination of bilirubin with the photometric colorimeter. J Biol Chem 1937; 119: 481-490.

16. Gornall AG, Bardwill CJ, David MM. Determination of serum proteins by means of the biuret reaction. $J$ Biol Chem 1949; 177: 751-756.

17. Ohkawa $H$, Onishi $N$, Yagi K. Assay for lipid peroxidation in animal tissue by thiobarbituric acid reaction. Anal Biochem 1979; 95: 351-358.

18. Ellman GL. Tissue sulphydryl groups. Arch Biochem Biophys 1959; 82: 70-77.

19. Kakkar $P$, Das $B$, Viswanathan PN. A modified spectrophotometric assay of superoxide dismutase. Ind J Biochem Biophys 1984; 21: 131132.

20. Aebi H. Catalase. In: Bergmeyar (eds). Methods in enzymatic analysis, New York, Academic Press, 1974, pp 674-684.

21. Tirmenstein MA, Nelson SP. Sub cellular binding and effects on calcium homeostasis produced by acetaminophen and a non-hepatotoxic regioisomer 3-hydroxyacetanilide in mouse liver. J Biol Chem 1989; 264: 9814-9819.
22. Vermeulen NPE, Bessems JGM, Van DE, Straat $R$. Molecular aspects of paracetamol-induced hepatotoxicity and its mechanism based prevention. Drug Metab Rev 1992; 24: 367-407.

23. Vaishwanar I, Kowale CN. Effect of two ayurvedic drugs Shilajeet and Eclinol on changes in liver and serum lipids produced by carbontetrachloride. Ind J Exp Biol 1976; 14: 58-61.

24. Sallie R, Tredger JM, Willaiam. Drugs and the liver. Biopharm Drug Dispos 1999; 12: 251-259.

25. Moss DW, Butterworth PJ. Enzymology and Medicine, London, Pitman Medical, 1974, p139.

26. Prakash J, Gupta SK, Kochupillai V, Singh N, Gupta YK, Joshi S. Chemopreventive activity of Withania somnifera in experimentally induced fibrosarcoma tumo-urs in swiss albino mice. Phytother Res 2001; 15: 240-244.

27. Scott MD, Lubin BH, Zuo L, Kuypers FA. Erythrocyte defense against hydrogen peroxide: Preeminent importance of Catalase. J Lab Clin Med 1991; 118: 7-16.

28. Chance B, Green Stein DS, Roughton RJW. The mechanism of catalase action l-steady state analysis. Arch Biochem Biophys 1952; 37: $301-$ 339. 